\title{
GROWTH PERFORMANCE AND GONAD MATURATION OF AMUR CATFISH, Silurus asotus IN CAPTIVITY
}

\author{
SARI ASFARINA SARIAT ${ }^{1}$, CHING FUI FUI $^{1 *}$ and SHIGEHARU SENOO ${ }^{2}$ \\ ${ }^{1}$ Borneo Marine Research Institute, Universiti Malaysia Sabah, \\ Jalan UMS, 88400, Kota Kinabalu, Sabah, Malaysia \\ ${ }^{2} U M S$-Kindai Aquaculture Development Center, Kindai University, \\ Shirahama, Wakayama, 649-2211, Japan \\ *E-mail: cfuifui@ums.edu.my
}

Accepted 13 September 2020, Published online 31 December 2020

\begin{abstract}
This study was aimed to determine the growth performance and gonad maturation of Amur catfish, Silurus asotus reared in captivity. A total of 600 juvenile Amur catfish were reared in a 20-tonne aerated fibreglass tank for 3 months. The changes to body weight (mean $\pm \mathrm{SD}$ ) of Amur catfish at day 14 was $22.59 \pm 3.59 \mathrm{~g}$ and attained a final average body weight of 110.95 $\pm 19.72 \mathrm{~g}$. The average body weight gains (\%) were $213.50 \%$ and gradually decreased to $109.95 \%$. The specific growth rate recorded at 14 -day intervals was $5.42 \%$ /day and fluctuated to $3.32 \% /$ day, $0.39 \% /$ day, $0.51 \% /$ day, with the corresponding measurements of $15.36 \pm 1.07 \mathrm{~cm}$ and increments to $24.22 \pm 1.34 \mathrm{~cm}$. The final total length the fishes attained was an average of $25.58 \pm 1.95 \mathrm{~cm}$. The total length gain recorded was $124.61 \%$ and followed by $109.95 \%$. The survival of Amur catfish within the three months was $29.17 \%$. Length-weight relationship of the Amur catfish showed a strong correlation at $\log \mathrm{W}=-2.6797+2.3102 \log \mathrm{L}$ and the value of the regression coefficient (b) equalled to 2.3102. Three stages of the oocyte $(\mathrm{PO}=$ primary oocyte, $\mathrm{PVO}=$ previtellogenic oocyte and $\mathrm{VO}=$ vitellogenic oocyte $)$ determined histologically indicated that all-female gonad samples were in the developing stage. Matured gonad and spermatozoa were also observed in males. This study concludes that Amur catfish attained good growth performance and fast gonad maturation in captivity and can be a suitable species for aquaculture.
\end{abstract}

Key words: Amur catfish, growth performance, gonad maturation, length-weight relationship, captivity

\section{INTRODUCTION}

The Amur catfish, Silurus asotus which is also known as the Japanese catfish, Chinese catfish and Far Eastern catfish is a freshwater species from the family of Siluridae. Amur catfish is well known as a carnivorous fish and is widely distributed in Japan (Miyadi et al., 1976) but is also found in East Asian countries including China, Korea, Taiwan and Vietnam (Kim et al., 2005). Amur catfish has a high value as it is consumed regularly, thus has become an important species in aquaculture. In Korea, the annual production of Amur catfish is about 8,000 metric tonnes, while in Vietnam, they are harvested throughout the year from the natural habitat (Huckstorf, 2012; Yang et al., 2015; Gil et al., 2017). The high number of fishes available in the natural habitat reflects its high fecundity in the wild.

\footnotetext{
* To whom correspondence should be addressed.
}

However, the continuous harvest of Amur catfish from the wild might deplete their numbers faster than their spawning capacity. Hence, aquaculture production of Amur catfish is needed to sustain a sufficient supply.

The Amur catfish is a warm water fish inhabiting water temperatures ranging from 20 to $27^{\circ} \mathrm{C}$ with preference to the soft ground (Yang et al., 2015). In Lake Biwa, Japan, the average water temperature is reported between $15.8^{\circ} \mathrm{C}$ to $26.7^{\circ} \mathrm{C}$ during the spawning season (Maehata, 2007). According to Lam (1983), for many temperate fish species, their gonadal development is triggered by seasonal photo-thermal spawning from early May to early July (Katano et al., 1988; Kobayakawa, 1989). Thus, production is limited and this leads to failure in meeting the increasing demand for Amur catfish among consumers. By adopting higher controlled temperatures in captivity, the growth performance, sex and gonad maturation of Amur catfish were determined in this study. 


\section{MATERIALS AND METHODS}

\section{Fish procurement}

Amur catfish was procured in 2018 through a research collaboration between the Universiti Malaysia Sabah (UMS) and Kindai University of Japan. The import permit for this species was granted by the Sabah Department of Fisheries solely for research purpose.

\section{Rearing system and management}

This study was conducted at the fish hatchery of Borneo Marine Research Institute (BMRI), Universiti Malaysia Sabah. The Amur catfish used were obtained through the artificial seeding production methods.

In this experiment, a total of 600 juvenile Amur catfish with an approximate body weight of 22.59 $\pm 3.59 \mathrm{~g}$ and total lengths of $15.36 \pm 1.07 \mathrm{cM}$ were collected and reared in a 20-tonne fibreglass tank. The tank was aerated throughout the experiment duration. A formulated feed (crude protein: 44\%, crude lipid: $8 \%$ ) was given twice per day at 0800 and $1500 \mathrm{hr}$ until satiety was reached. Bottom cleaning and $10 \%$ water renewal was conducted every two days. The water quality was maintained at temperature: $29.33 \pm 1.73^{\circ} \mathrm{C}$, dissolved oxygen: $5.10 \pm 0.27 \mathrm{mg} / \mathrm{L}$ and $\mathrm{pH}: 8.34 \pm 0.05$.

\section{Growth performance}

Growth measurement was carried out every two weeks for three months. Before measurement was carried out, all Amur catfish were anaesthetized (Transmore, NIKA, Malaysia). Fish body weight (g) and total length (cM) were also measured. Growth performances were expressed as the mean body weight, body weight gained (BWG), total length gained (TLG) and specific growth rate (SGR). During the experiment, any mortality was counted and recorded daily. BWG, TLG, SGR and survival rate were calculated according to the following formulae:

$$
\begin{aligned}
& B W G(\%)=\frac{\text { Final weight }(\mathrm{kg})}{\text { Initial weight }(\mathrm{kg})} \times 100 \\
& T L G(\%)=\frac{\text { Final length }(\mathrm{cM})}{\text { Initial length }(\mathrm{cM})} \times 100 \\
& S G R(\% / \text { day })=\frac{(\text { In final weight }- \text { In initial weight })}{\text { Days }} \times 100
\end{aligned}
$$$$
\text { Survival }(\%)=\frac{\text { Final number of fish }}{\text { Initial number of fish }} \times 100
$$

\section{Body indices and sex determination}

At the end of the experiment (day 90), fifty Amur catfishes were sacrificed and dissected to determine the body indices and sex determination. Before dissection, BW and TL were measured. Each fish was photographed with a ruler as a reference scale. Other morphometric measurement features such as the presence of genital pore and genital papillae were also recorded. Biopsy analysis of gonad was done for fifty individual Amur catfish to confirm the presence of eggs and sperm, followed by dissection to obtain the gonads. Samples were preserved in $10 \%$ formalin for further histology processing. The length-weight relationship between total length (L) and body weight $(\mathrm{W})$ were expressed and calculated using the equation below:

$$
\mathrm{W}=\mathrm{aL}^{\mathrm{b}}
$$

Fulton's condition factor $(\mathrm{K})$ was estimated from the relationship to assess the fish condition using the formula below:

$$
K=100 W / L^{3}
$$

Where,

$\mathrm{W}=$ weight in gram

$\mathrm{L}=$ length in centimetre

Viscera somatic index (VSI) was also calculated to assess the fish condition. To calculate the viscera somatic index, the following formula was used (Mohammad et al., 2016):

$$
V S I=\frac{\text { Viscera weight }(g)}{\text { Fish weight }(g)} \times 100
$$

\section{Histological analysis}

Histological analysis was conducted to observe the gonad maturation stage for both ovary and testis. The histological steps were fixation in Davidson's solution, dehydration in graded ethanol series and immersion in xylene twice for clearing processes. The samples were then embedded in paraffin, sectioned to $65 \mathrm{M}$, mounted on glass slides and lastly stained with haematoxylin and eosin (HE). Egg development and maturation stages of the histology slides were observed using a compound light microscope (Microscope, Omax, China) concerning Luin et al. (2013) and Çek and Yilmaz (2005). 
Table 1. Growth performances of Amur catfish, Silurus asotus cultured for twelve weeks under controlled condition in captivity

\begin{tabular}{lccccccc}
\hline \multirow{2}{*}{$\begin{array}{l}\text { Growth } \\
\text { performances }\end{array}$} & \multicolumn{7}{c}{ Weeks } \\
\cline { 2 - 8 } & 0 & 2 & 4 & 6 & 8 & 10 & 12 \\
\hline BWC (g) & $22.59 \pm 3.59$ & $48.22 \pm 11.71$ & $76.70 \pm 15.22$ & $80.99 \pm 19.77$ & $87.01 \pm 7.83$ & $100.91 \pm 3.59$ & $110.95 \pm 19.72$ \\
BWG (\%) & - & 213.50 & 159.06 & 105.59 & 107.44 & 115.97 & 109.95 \\
SGR (\%/day) & - & 5.42 & 3.32 & 0.39 & 0.51 & 1.06 & 0.68 \\
TLC (cm) & $15.36 \pm 1.07$ & $19.14 \pm 1.07$ & $22.36 \pm 1.63$ & $22.84 \pm 1.79$ & $22.56 \pm 2.43$ & $24.22 \pm 1.34$ & $25.58 \pm 1.95$ \\
TLG (\%) & - & 124.61 & 159.06 & 105.59 & 107.44 & 115.97 & 109.95 \\
\hline
\end{tabular}

\section{RESULTS}

\section{Survival and growth}

The growth performances of Amur catfish cultured for three months in captivity are presented in Table 1. The Amur catfish with the initial body weight mean $\pm \mathrm{SD}$ of $22.59 \pm 3.59 \mathrm{~g}$ attained a final body weight of $110.95 \pm 19.77 \mathrm{~g}$ with a bodyweight gain of $213.50 \%$ /day, $159.06 \%$ /day, $105.68 \%$ /day for every 14-day interval, respectively. As for total length, Amur catfish with the initial total length mean $\pm \mathrm{SD}$ of $15.36 \pm 1.07 \mathrm{cM}$ attained a final total length of $25.58 \pm 1.95 \mathrm{cM}$ with the total length gain of $124.61 \%, 159.06 \%, 105.59 \%, 107.44 \%, 115.97 \%$ and $109.95 \%$ for every 14 -day interval respectively. The survival rate of Amur catfish observed within three months of rearing was $29.17 \%$.

\section{Body indices}

From 50 juveniles of Amur catfish, the sex ratio of males to females was at 29:21. The graph shows goodness-of-fit, R2 $=0.7334$ and negative allometry length-weight growth with $b=2.3102$ (Figure 1 and Figure 2). Meanwhile, the condition factor, $\mathrm{K}$ of the Amur catfish was 0.69 and 0.94 for the male and female fishes respectively (Table 2). The viscera somatic index (VSI) of Amur catfish was $8.20 \pm 1.58$ and $8.64 \pm 1.63$ for the male and female fishes respectively. Results indicated that the fish was in good condition throughout the experiment.

\section{Gonad maturation}

For the histological investigation, the vitellogenesis of oocyte can be seen in Figure 3. All three

Table 2. Condition factors and viscera somatic index (\%) for 50 juveniles of Amur catfish, Silurus asotus cultured for twelve weeks period under controlled condition in captivity

\begin{tabular}{lcc}
\hline Preferences & Male & Female \\
\hline Condition factor, K & 0.69 & 0.94 \\
VSI $(\%)$ & $8.20 \pm 1.58$ & $8.64 \pm 1.63$ \\
\hline
\end{tabular}

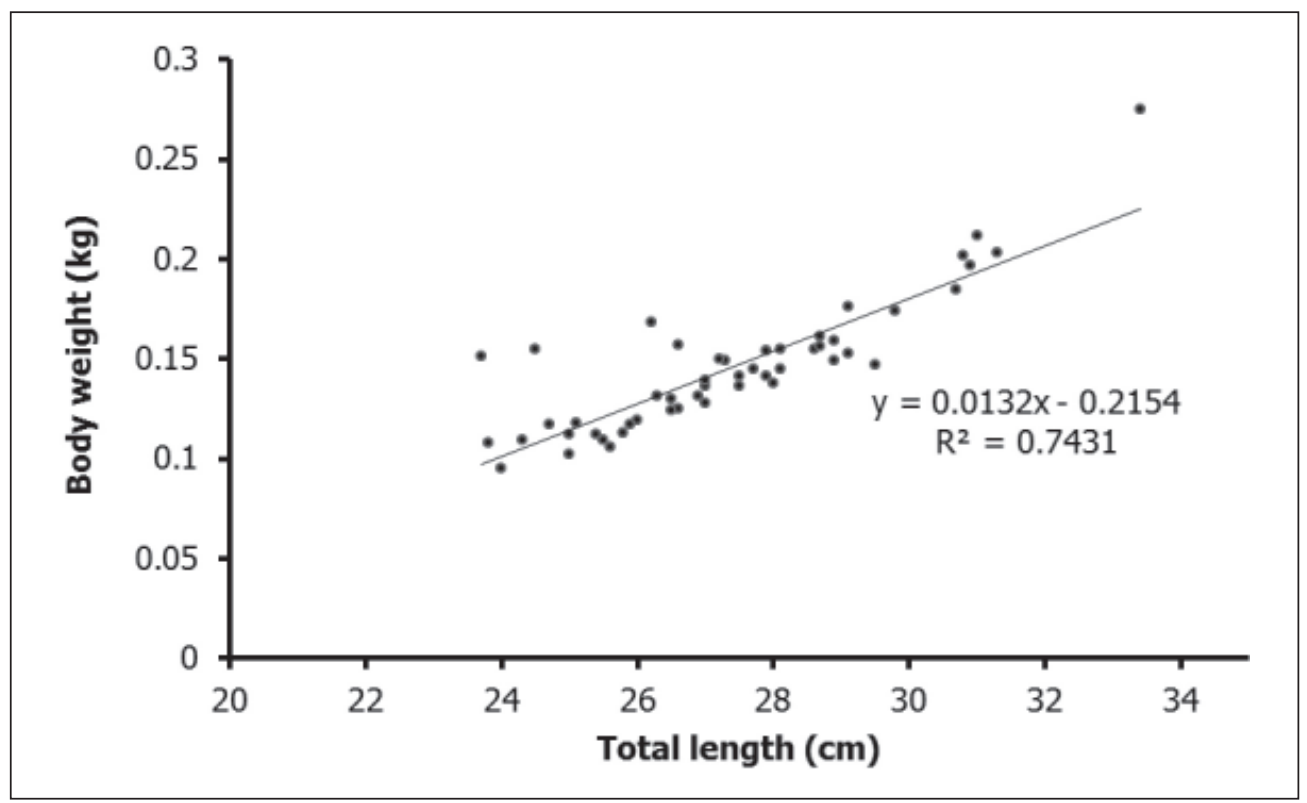

Fig. 1. Body weight against total length of 50 juveniles of Amur catfish, Silurus asotus cultured for twelve weeks period under controlled condition in captivity. 


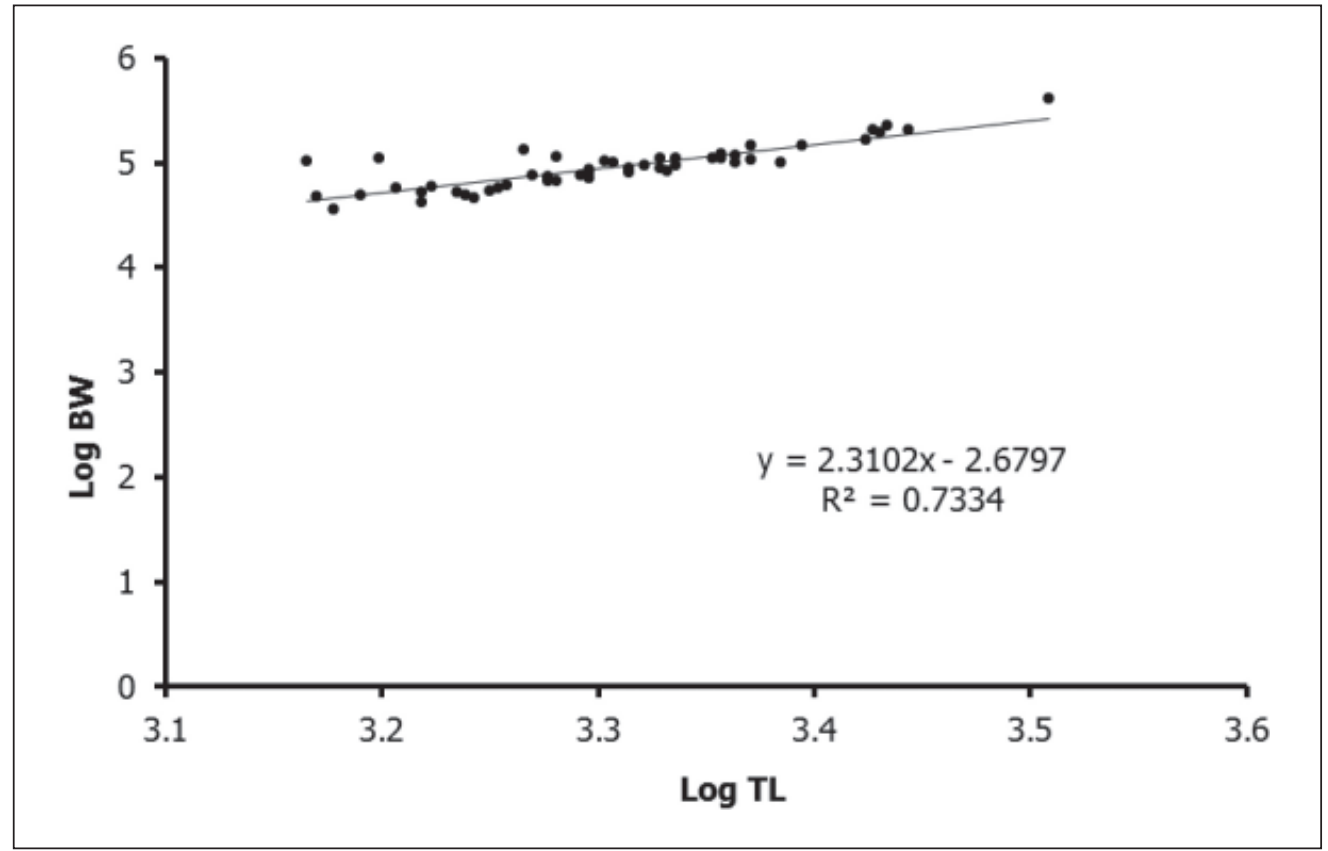

Fig. 2. Regression equation for Amur catfish, Silurus asotus showing $\ln B W=2.3102$, $\ln \mathrm{TL}=2.6797$ shows goodness-of-fit with $R^{2}=0.7334$ when cultured for twelve weeks under controlled condition in captivity.

Table 3. Gonadal stages for female Amur catfish, Silurus asotus cultured in twelve weeks period under controlled condition in captivity

\begin{tabular}{lcccccc}
\hline Sample & Bodyweight $(\mathrm{g})$ & Total length $(\mathrm{cM})$ & No. of PO & No. of PVO & No. of VO & Gonadal stage \\
\hline Ovary 01 & 185 & 30.7 & 7 & 23 & 2 & Developing \\
Ovary 02 & 202 & 30.8 & 21 & 18 & 10 & Developing \\
Ovary 03 & 155 & 28.1 & 18 & 17 & 3 & Developing \\
Ovary 04 & 102 & 25.0 & 9 & 10 & 1 & Developing \\
Ovary 05 & 124 & 26.5 & 28 & 25 & 2 & Developing \\
Ovary 06 & 113 & 25.8 & 39 & 29 & 1 & Developing \\
Ovary 07 & 108 & 23.8 & 37 & 19 & - & Developing \\
\hline
\end{tabular}

stages of oocyte can be seen for all female gonads. They are primary oocyte (PO), previtellogenic oocyte (PVO) and vitellogenic oocyte (VO).

For Ovary 01 , the total amount of PO was 7, PVO was 23 and VO was 2 (Table 3). This shows that the gonadal stage for the first ovary was still developing. Similar findings were observed in Ovary 03, with the presence of PO and PVO stage indicating the females were in the developing phase. However, for Ovary 02, it was shown that it had the highest VO count, which indicated that the gonads are closer to maturation, thus are available for spawning.

As for male gonads, phases of spermatogenesis were distinguishable based on their nuclear characteristic and cytoplasmic morphologies. Spermatozoa were detected in the male testis of the Amur catfish (Figure 4) and it showed that the gonadal stage for the testis was in the mature stage
(Table 4). It can be concluded that spermatozoa in Amur catfish can be observed as early as three months of age.

\section{DISCUSSION}

\section{Growth performance}

Similarly to a report by Yang et al. (2015), Amur catfish displayed excellent growth rate in this study, reflecting that the growth performance of Amur catfish was equally good to that of other aquaculture fish species. Under a controlled temperature, juvenile Amur catfish can reach a bodyweight $200 \mathrm{~g}$ of with a total length of $30 \mathrm{~cm}$ in approximately 4-months duration. Despite being slower in body weight development compared to adult African catfish (Clarias gariepinus), in natural and farming conditions, which can grow up to 


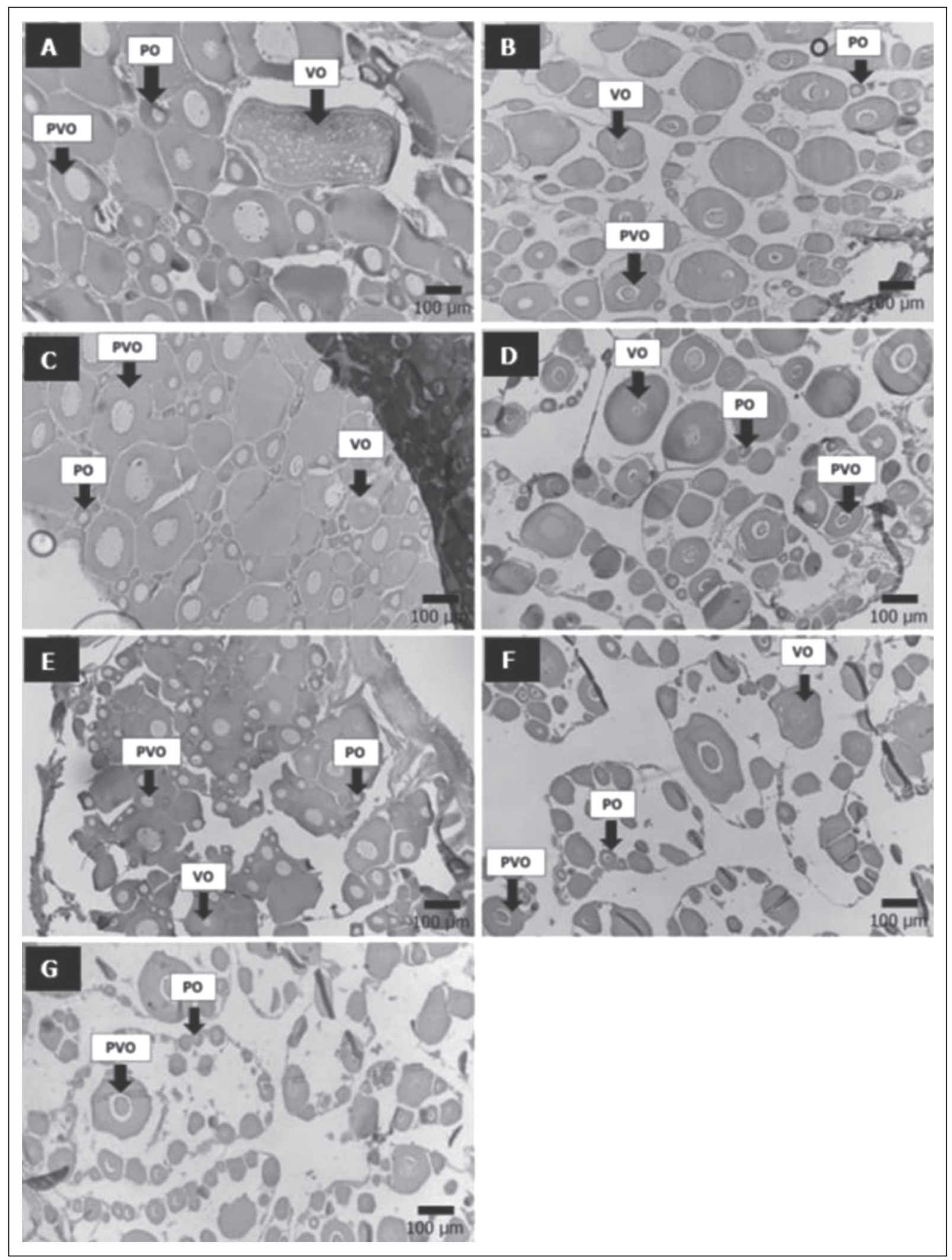

Fig. 3. Histological slide of female gonad of Amur catfish, Silurus asotus cultured in twelve weeks period under controlled condition in captivity. (A) Ovary 01; (B) Ovary 02; (C) Ovary 03; (D) Ovary 04; (E) Ovary 05; (F) Ovary 06; (G) Ovary 07. Abbreviations: PO, primary oocytes; PVO, previtellogenic oocyte; VO, vitellogenic oocyte. 


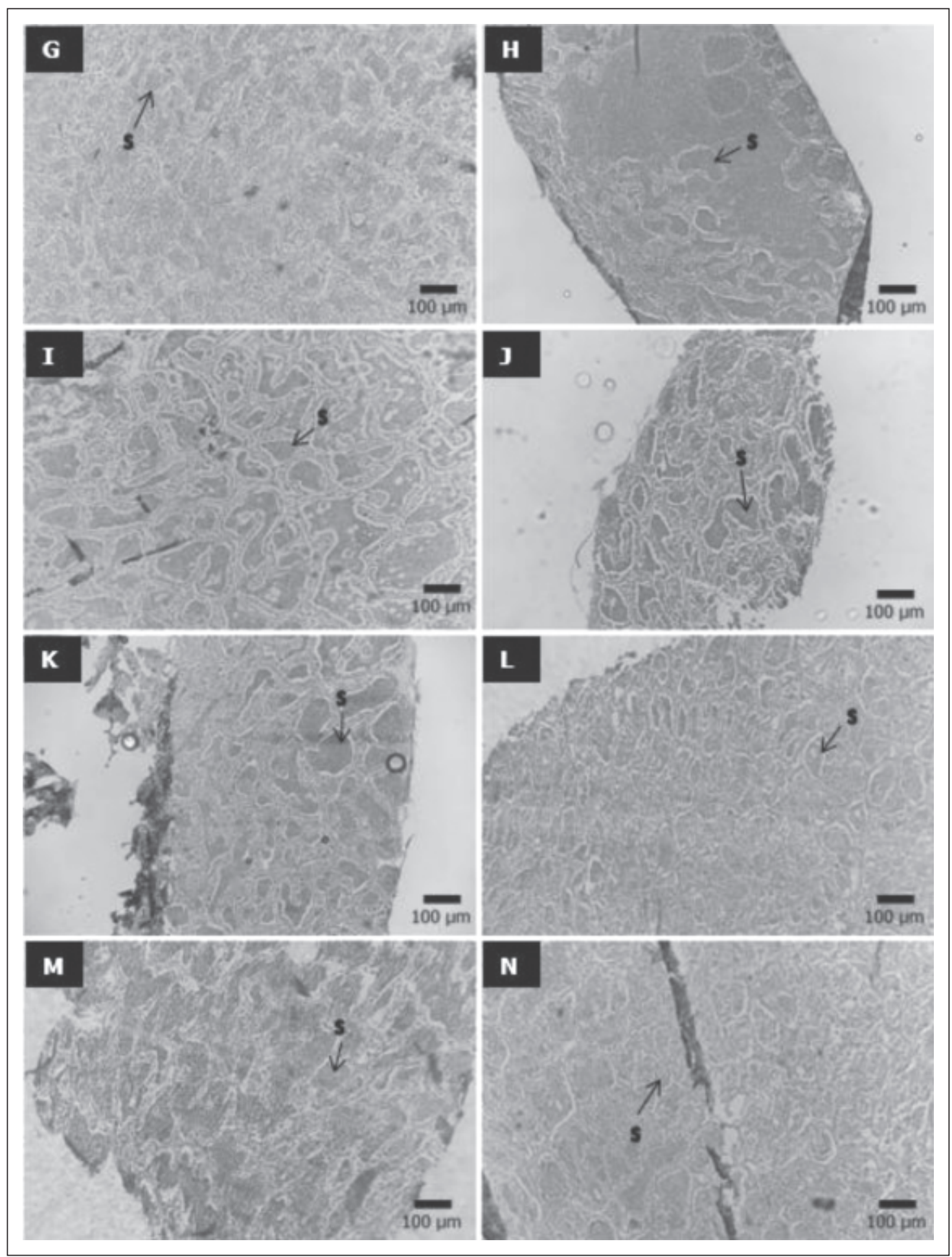

Fig. 4. Histological slide of male gonad of Amur catfish, Silurus asotus cultured in twelve months period under controlled condition in captivity (G) Testis 01; (H) Testis 02; (I) Testis 03; (J) Testis 04; (K) Testis 05; (L) Testis 06; (M) Testis 07; (N) Testis 08. Abbreviation: S, Spermatozoa.

$400 \mathrm{~g}$ in 4 months. Yamamoto (2017) reported that the growth performance of newly hatched larvae of Amur catfish larvae took about 14 days to reach $2.4 \mathrm{cM}$ in length while African catfish took 20 to 30 days after hatching to reach a similar size. The shorter duration is beneficial to farmers in obtaining
Amur catfish seeds in a relatively shorter time compared to the African catfish, hence making Amur catfish a good species candidate for aquaculture from the early stage.

Although the growth performance of Amur catfish seems to slow down upon entering the adult 
Table 4. Gonadal stage for male Amur catfish, Silurus asotus cultured in twelve months period under controlled condition in captivity

\begin{tabular}{lcccc}
\hline Sample & Bodyweight $(\mathrm{g})$ & Total length $(\mathrm{cM})$ & Spermatozoa & Gonadal stage \\
\hline Testis 01 & 176 & 29.1 & Detected & Mature \\
Testis 02 & 156 & 31.0 & Detected & Mature \\
Testis 03 & 141 & 27.9 & Detected & Mature \\
Testis 04 & 106 & 25.6 & Detected & Mature \\
Testis 05 & 149 & 27.3 & Detected & Mature \\
Testis 06 & 119 & 26.0 & Detected & Mature \\
Testis 07 & 174 & 29.8 & Detected & Mature \\
Testis 08 & 150 & 27.2 & Detected & Mature \\
\hline
\end{tabular}

stage, readings were similar to those reported in many other freshwater fish species (Choi et al., 1992). In the adult stage upon attaining sexual maturity, Amur catfish begin to experience reduced growth and decreased feeding efficiency. This is presumably due to a mechanism used by the fish to channel energy for sexual maturation rather than to support its somatic growth. Choi et al. (1992) also reported that the usual sexual maturation of Amur catfish commences as early as 3-4 months of age when the fish has not reached marketable size $(250 \mathrm{~g})$ and such precocious maturation results in lowered growth rate and decreased feeding efficiency until they reach marketable size. Similar findings were observed in this study, whereby, at approximately 3 months of age the Amur catfish body weight was below $250 \mathrm{~g}$. Hence, this may be a factor responsible for the sudden static growth upon entering into the adult stage.

In Japan, the growth performance of Amur catfish was further improved when diets are specially made to meet the fish's nutritional requirements. Kim et al. (2014) reported that the specific growth rate of Amur catfish fed with diets containing different protein levels (20 to 40\%) to be at 2.24 to $2.60 \%$ per day. In this experiment, the Amur catfish were fed with a commercially formulated feed containing $44 \%$ crude protein and this contributed to a specific growth rate as high as $5.42 \%$ /day but later reduced and fluctuated to $3.32 \% /$ day, $0.39 \% /$ day, $0.51 \% /$ day, $1.06 \% /$ day and $0.68 \%$ /day respectively over time. Under a controlled temperature in captivity, Amur catfish are seen to be able to adapt owing its hardiness to tolerate a wide range of water temperature although Amur catfish spend most of their time in temperate regions as those commonly found in Japan, Korea, Northern Thailand and Vietnam. This feature also makes Amur catfish a good aquaculture species under controlled conditions.

\section{Survival}

The low survival of Amur catfish in this study might be due to several factors, such as cannibalism, fish handling and rearing techniques as similarly reported by McGovern and Olney (1996). Survival is highly associated with and be affected by various abiotic and biotic factors, including lethal environmental conditions, starvation, and predation. Amur catfish is not a common aquaculture fish species, hence its handling and rearing techniques are not well established and often subjected to various unknown factors that might lead to low survival rates.

Amur catfish are well known as a carnivorous species, however, carnivorous behaviour of the Amur catfish was observed to be more aggressive than expected and this led to mass shock-associated mortality. In aquaculture, cannibalism has been highly reported particularly in larval and juvenile stages (Pereira et al., 2017). In contrast to the adult stage, only a few cannibalistic behaviour studies had been reported perhaps owing to its established survival strategy and adaptation to the environment. Cannibalism is often seen during natural spawning in which triggered when the cost of care is high and may be influenced by brood size and age, parental body condition, local abundance of males, and degree of certainty of paternity (Kondoh \& Okuda, 2002; Manica, 2004). In this study, cannibalistic behaviour was not seen as artificial spawning was performed whereby both female and male broodstock were isolated separately, however, the aggressiveness of broodstock was detected while being handled. According to Hect and Pienaar (1993), size variation is also a primary cause of agonistic behaviour, which in turn can have the same end effect as cannibalism. Hecht and Appelbaum (1988) and Van Damme et al. (1989), however, viewed size variation both as a cause and effect of cannibalism. Amur catfish have also shown sexual dimorphisms, whereby females grow faster than males (Kim et al., 2001). Hence, females tend to be more aggressive and attack males thus subsequently contributing to higher mortality (Seol et al., 2008). 


\section{Body indices}

The length-weight relationship provides information on the changes in fish well-being during their life cycle. In this study, regression coefficients (b) of the length-weight relationship was $b=2.310$. Therefore, it was revealed that Amur catfish showed negative allometric growth. According to Riedel et al. (2007), negative allometric $(b<3)$ implies that the fish becomes more slender as it grows in length. This result suggests that the progression of growth in terms of body weight and the total length would generate healthy and robust fishes. The relationship established through the regression method used to understand the fish well-being by assessing the condition factor. The condition factor indicated that the fishes were in a good, healthy condition throughout the experiment, in which the value for males and females were 0.69 and 0.94 , respectively. This study suggests that more studies should be conducted, particularly on establishing the best rearing techniques of Amur catfish to improve their growth.

\section{Gonad maturation}

In the present study, spermatozoa were detected in all the male Amur catfish samples which indicated a mature gonad. Thus, male Amur catfish can mature as early as 3 months of age under controlled temperatures and with an average body weight of 146 g. Compared to the African catfish, they reach an age of the first maturity at 12 months (Yalçın et al., 2001). The fast maturation of Amur catfish compared to the African catfish and other freshwater fish is an important characteristic. In female gonads, the histology results showed a large variation in the oocyte stage. They are primary oocyte, previtellogenic oocyte and vitellogenic oocyte stages. All three oocyte cells were found in the female gonads. Since vitellogenesis is detected in all-female gonad samples, this indicated that the gonads are closer to maturation thus are available for spawning. A previous study reported that female Japanese catfish matured 1 year after hatching under specific rearing conditions without any environmental manipulation such as regulation of the photoperiod or water temperature (Kumakura et al., 2003). Meanwhile, Inaba (1976) reported that, in wild Amur catfish, the age of the first maturity is 2 years when their body weight was approximately 200-300 g. In the present study, female Amur catfish attained $200 \mathrm{~g}$ in BW and were closer to maturation at 3 months of age. This certainly makes Amur catfish a good species for aquaculture when maturation can be attained in a shorter time under captivity compared to those reported in the wild. Rapid maturation may have been caused by the frequent feeding compared to the wild which hastened the onset of maturation. According to Kumakura et al. (2003), in temperate zones, most species of the teleost fish are seasonal spawner and there is variation in the time of year when spawning occurs. Thus, in the present study, the controlled temperature might be favourable for this species to spawn in captivity.

\section{CONCLUSION}

This study concludes that growth performances of Amur catfish are equally good as other tropical catfish species particularly in comparison to the African catfish as reported in many publications. The gonadal development of Amur catfish shows that they can mature in a shorter period compared to those reported in the wild and also those cultured under lower temperatures. By taking both the excellent growth performances and gonad maturation of the Amur catfish under controlled temperature in captivity into account, Amur catfish can be potentially introduced into the aquaculture industry.

\section{ACKNOWLEDGEMENTS}

The authors thank the staffs and students in Fish Hatchery of Borneo Marine Research Institute, Universiti Malaysia Sabah and Kindai University, Japan for their undivided support and technical assistance throughout the study. This study was funded by the Research Collaboration Grant Scheme (Grant code: GKP0002-STWN-2016) between Universiti Malaysia Sabah and Kindai University, Japan.

\section{REFERENCES}

Ayo-Olalusi, C.I. 2014. Length-weight relationship, condition factor and sex ratio of African Mud Catfish (Clarias gariepinus) reared in flowthrough system tanks. Journal of Fisheries and Aquatic Science, 9(5): 430-434.

Çek, S. \& Yilmaz, E. 2005. Gonad development and sex ratio of Sharptooth Catfish (Clarias gariepinus Burchell, 1822) Cultured under Laboratory Conditions. Turkish Journal of Zoology, 31: 35-46.

Choi, G.C., Kim, D.S., Jo, J-Y. \& Kim, J.M. 1992. Induced breeding and indoor culture of the catfish (Silurus asotus) (Teleostomi: Siluridae). Journal of Aquaculture, 5: 117-126. 
Gill, H.W., Lee, T.H. \& Park, I.S. 2017. Effects of cryoprotectants and diluents on the cryopreservation of spermatozoa from Far Eastern Catfish, Silurus asotus. Development \& Reproductive, 21(1): 79-91.

Huckstorf, V. 2012. Silurus asotus. The IUCN Red List of Threatened Species 2012 [WWW Document]. URL http://dx.doi.org?10.2305/ IUCN.UK.2012-1.RLTS.T166951A1156283 (accessed 8.17.2017).

Inaba, D. 1976. Freshwater Aquaculture. Koseisha Koseikaku, Tokyo.

Katano, O., Saitoh, K. \& Koizumi, A. 1988. ScatterSpawning of the Catfish, Silurus asotus. Japanese Journal of Ichthyology, 35(2): 203211.

Kim, D.S., Cho, H.J., Bang, I.C., Choi, G.C. \& Nam, Y.K. 2014. Effects of immersion of larvae in Oestradiol-17] on feminization, structural changes of gonad and growth performance in the Far Eastern Catfish, Silurus asotus (Linnaeus). Aquaculture Research, 32: 323-328.

Kim, D.S., Cho, H.J., Park, I.S., Choi, G.C. \& Nam Y.K. 2001. Cytogenetic traits and gonad development of induced triploidy in Far Eastern Catfish (Silurus asotus). Gene and Genomic, 23: 55-2.

Kim, I.S., Choi, Y., Lee, C.L., Lee, Y.J., Kim, B.J. \& Kim, J.H. 2005. Illustrated Book of Korean Fishes. Kyok-Hak Pub Co., Korea.

Kobayakawa, M. 1989. Far Eastern Catfish. In: Japanese Freshwater Fishes. H. Kawanabe and N. Mizuno (Eds.). Yama-Kei Publisher, Tokyo. Pp. 412-415.

Kondoh, M. \& Okuda, N. 2002. Mate availability influences filial cannibalism in fish with paternal care. Animal Behaviour, 63: 227-233.

Kumakura, N., Sakai, K. \& Takashima, F. 2003. Reproductive cycle and human chorionic gonadotrophin-induced ovulation in hatchery reared Japanese Catfish Silurus asotus. Fisheries Science, 69: 495-504.

Lam, T.J. 1983. Environmental influences on gonadal activity in fish. In: Fish Physiology, Reproduction. W.S. Hoar, D.J. Randall and E.M. Donaldson (Eds.). Academic Press, New York. pp. 65-116.

Luin, M., Fui, C.F. \& Senoo, S. 2013. Sexual maturation and gonad development in Tiger Grouper (Epinephelus fuscoguttatus) $\times$ Giant Grouper (E. lanceolatus) Hybrid. Journal of Aquaculture Research \& Development, 5: 2.

Maehata, M. 2007. Reproductive ecology of the Far Eastern Catfish, Silurus asotus (Siluridae), with a comparison to its two congeners in Lake Biwa, Japan. Environmental Biology Fish, 78: 135-146.
Manica, A. 2004. Parental fish change their cannibalistic behaviour in response to the cost-to-benefit ratio of parental care. Animal Behaviour, 67: 1015-1021.

McGovern, J.C. \& Olney, J.E. 1996. Factors affecting survival of early life stages and subsequent recruitment of striped bass on the Pamunkey River, Virginia. Canadian Journal of Fisheries and Aquatic Sciences, 53: 17131726.

Miyadi, D., Kawanabe, H. \& Mizuno, N. 1976. Colored Illustrations of the Freshwater Fishes of Japan. Hoikusha, Osaka. pp 462.

Munir, M.B., Hashim, R., Abdul Manaf, M.S. \& Mohd Nor, S.A. 2016. Dietary prebiotics and pobiotics influence the growth performance, feed utilisation, and body indices of Snakehead (Channa striata) fingerlings. Tropical Life Sciences Research, 27(2): 111-125.

Park, I.S., Im, J.H. \& Hur, J.W. 2004. Morphometric characteristic of Catfish (Siluridae) in Korea. Korean Journal of Ichthyology, 16: 223-228.

Pereira, L.S., Agostinho, A.A. \& Winemiller, K.O. 2017. Revisiting cannibalism in fishes. Reviews in Fish Biology and Fisheries, 27: 499-513.

Riedel, R., Caskey, L.M. \& Hurlbert, S.H. 2007. Length-weight relations and growth rates of dominant fishes of the Salton Sea: Implication for predation by fish-eating birds. Lake and Reservoir Management, 23(5): 28-535.

Seol, D.W., Im, S.Y., Hur, W.J, Park, M.O., Kim, D.S., Jo, J.Y. \& Park, I.S. 2008. Haematological parameters and respiratory function in diploid and triploid Far Eastern Catfish, Silurus asotus. Genes and Genomics, 30: 205-213.

Tyler, C.R., Sumpter, J.P., Kawanchi, H. \& Swanson, P. 1991. Involvement of gonadotrophin in the uptake of vitellogenin into vitellogenic follicles of the rainbow trout, Oncorhynchus mykiss. General and Comparative Endocrinology, 84: 291-299.

Yalçın, S. Solak, K. \& Akyurt, I. 2001. Certain reproductive characteristics of the African Catfish (Clarias gariepinus Burchell, 1822) living in the River Asi, Turkey. Turkish Journal of Zoology, 25: 453-460.

Yamamoto, S. 2017. The egg development and larval rearing of Japanese catfish, Silurus asotus in tropical region, Malaysia. Universiti Malaysia Sabah, Sabah.

Yang, W.S., Gil, H.W., Yoo, G.Y. \& Park, I.S. 2015. Identification of skeletal deformities in Far Eastern Catfish, Silurus asotus under indoor aquaculture condition. Development \& Reproductive, 19(3): 153-161. 
